\title{
Limits of temperature adaptation and thermopreferendum
}

\author{
K. B. Aslanidi* ${ }^{*}$ and D. P. Kharakoz ${ }^{\wedge}$
}

\begin{abstract}
Background: Managing the limits of temperature adaptation is relevant both in medicine and in biotechnology. There are numerous scattered publications on the identification of the temperature limits of existence for various organisms and using different methods. Dmitry Petrovich Kharakoz gave a general explanation for many of these experimental results. The hypothesis implied that each cycle of synaptic exocytosis includes reversible phase transitions of lipids of the presynaptic membrane due to the entry and subsequent removal of calcium ions from the synaptic terminal. The correspondence of the times of phase transitions has previously been experimentally shown on isolated lipids in vitro. In order to test the hypothesis of D.P. Kharakoz in vivo, we investigated the influence of the temperature of long-term acclimatization on the temperature of heat and cold shock, as well as on the kinetics of temperature adaptation in zebrafish. Testing the hypothesis included a comparison of our experimental results with the results of other authors obtained on various models from invertebrates to humans.

Results: The viability polygon for Danio rerio was determined by the minimum temperature of cold shock (about $6^{\circ} \mathrm{C}$ ), maximum temperature of heat shock (about $43^{\circ} \mathrm{C}$ ), and thermopreferendum temperature (about $27^{\circ} \mathrm{C}$ ). The ratio of the temperature range of cold shock to the temperature range of heat shock was about 1.3. These parameters obtained for Danio rerio describe with good accuracy those for the planarian Girardia tigrina, the ground squirrel Sermophilus undulatus, and for Homo sapiens.

Conclusions: The experimental values of the temperatures of cold shock and heat shock and the temperature of the thermal preferendum correspond to the temperatures of phase transitions of the lipid-protein composition of the synaptic membrane between the liquid and solid states. The viability range for zebrafish coincides with the temperature range, over which enzymes function effectively and also coincides with the viability polygons for the vast majority of organisms. The boundaries of the viability polygon are characteristic biological constants. The viability polygon of a particular organism is determined not only by the genome, but also by the physicochemical properties of lipids that make up the membrane structures of synaptic endings. The limits of temperature adaptation of any biological species are determined by the temperature range of the functioning of its nervous system.
\end{abstract}

Keywords: Adaptation, Temperature, Cold shock, Heat shock, Thermopreferendum, Viability polygon, Lipids

*Correspondence: kbaslanidi@gmail.com

${ }^{\dagger}$ D. P. Kharakoz passed away in 2012

Institute of Theoretical and Experimental Biophysics, Russian Academy

of Sciences, Pushchino, Moscow region, Russia 142290

\begin{abstract}
Introduction
Any living organism can exist only within a limited range of the ambient temperatures. The limits of the temperature adaptation are of particular importance for ectotherms - organisms that cannot control their body temperature and constantly have to adapt to the changes of the ambient temperature. In the course of adaptation, the lipid composition and physicochemical properties of
\end{abstract}

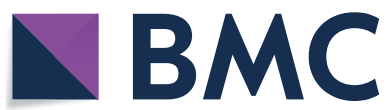

(c) The Author(s) 2021. This article is licensed under a Creative Commons Attribution 4.0 International License, which permits use, sharing, adaptation, distribution and reproduction in any medium or format, as long as you give appropriate credit to the original author(s) and the source, provide a link to the Creative Commons licence, and indicate if changes were made. The images or other third party material in this article are included in the article's Creative Commons licence, unless indicated otherwise in a credit line to the material. If material is not included in the article's Creative Commons licence and your intended use is not permitted by statutory regulation or exceeds the permitted use, you will need to obtain permission directly from the copyright holder. To view a copy of this licence, visit http://creativeco mmons.org/licenses/by/4.0/. The Creative Commons Public Domain Dedication waiver (http://creativecommons.org/publicdomain/ zero/1.0/) applies to the data made available in this article, unless otherwise stated in a credit line to the data. 
membranes in ectotherms undergo considerable changes $[1,2]$. During this adaptation process, neurons support unique lipid compositions with specific physicochemical properties [2]. Moreover, the composition and physicochemical properties of membrane lipids in ectotherms depend on the ambient temperature [1]. From early work on model membranes, it was known that the temperature of the phase transition of lipid membranes from the state of a liquid crystal to a solid gel state depends on the concentration of $\mathrm{Ca}^{2+}$ ions [3, 4].

Dmitry Petrovich Kharakoz was the first to draw attention to the fact that each cycle of synaptic exocytosis includes reversible phase transitions of lipids of the presynaptic membrane due to the entry and subsequent removal of calcium ions from the synaptic terminal $[5,6]$. According to this notion, lipid membrane has to be in a liquid-crystal state close to the phase transition temperature, and adaptation to various temperatures has to occur through the appropriate alterations in the lipid composition of the presynaptic membrane and synaptic vesicles. The hypothesis implied that the $\mathrm{Ca}^{2+}$-induced chainordering phase transition in the lipid component of synaptic membranes plays a key role in the neurotransmitter release [5]. It was proposed that the plasma membrane in the active zones of synaptic terminals contains selfassembling cooperative domains whose $\mathrm{Ca}^{2+}$-induced solidification may be the driving force of the fast neurotransmitter release in the central synapses [6]. It was shown that the phase-transitional mechanism can provide a high rate of synaptic exocytosis known for the fastest synapses in the central nervous system [7]. The important role of the mechanisms of fusion and breaking of synaptic membranes for the functioning of neural networks was noted by other authors $[8,9]$, however, they did not pay due attention to phase transitions in membranes. It should be noted that both approaches describe the disturbances in the action potential propagation at the level of presynaptic [5, 6] or postsynaptic [10] membranes and ascribe a key role to the alterations in the phase state of the lipid-protein compositions of the neuronal membrane [11-13]. Considering the temperature dependence of the intracellular $\mathrm{Ca}^{2+}$ content revealed earlier on the simplest models of cell's ionic-osmotic homeostasis $[14,15]$, the existence of the upper and lower temperature limits for synaptic exocytosis can be expected. At a temperature higher than the upper limit the presynaptic membrane will remain in a liquid state even during the action potential causing an increase in the intracellular $\mathrm{Ca}^{2+}$ concentration. Cooling the membrane to the temperatures lower than the lowest limit will also upset the synaptic conduction, as at any cytoplasmic concentration of $\mathrm{Ca}^{2+}$ the membrane will remain in a solid state. In both cases the neurotransmitter release will be stopped, and at the level of the whole organism this disturbance in the synaptic transmission can be recorded as a loss of righting reflex. The relation between the fluidity of the synaptic membranes and the loss of righting reflex was shown long ago [16]. Loss of righting reflex observed in the presence of narcotic drugs soluble in membrane lipids was explained by an increase in the membrane fluidity leading to disturbances of the nerve excitation conduction [16-18]. The mechanisms of the reversible assembly of synaptic vesicles at physiological temperature are generally understood [19]; however, temperature dependencies of the synaptic exocytosis are virtually unexplored. It is obvious that such investigations should be conducted on ectothermic animals that are able to survive in a wide range of temperatures. On the other hand, as far as no specific genes or neuroendocrine factors for hypometabolic states have been discovered by far, it is conceivable that endotherms, including humans, have a potential for this physiological state as well. Hypometabolism in newborn mammalians can serve a model for creation of such states in adult mammalians, including humans, for medical applications and for space exploration programs [20].

In order to test the hypothesis of D.P. Kharakoz in vivo, we investigated the influence of the temperature of longterm acclimation on the temperature of heat and cold shock, as well as the kinetics of temperature adaptation in zebrafish. Zebrafish Danio rerio is a typical exothermic animal that lives in a wide range of temperatures. The aim (goal) of this work was to identify the temperature range in which Danio rerio could survive and to compare these parameters with the results obtained in other biological species.

The experiment identified the temperatures at which the fish retains mobility driven by coordinated functions of the nerve and muscular systems. It is known that extreme changes in environmental temperatures cause a set of adaptive reactions that deteriorate the homeostasis of the body and lead to cold or heat shock. The stress temperature in exotherms depends on the adaptation temperature. For this purpose, we analyzed the dependence of the temperature, at which the synaptic transmission was disrupted (shock temperature), on ambient temperatures and adaptation time. The functional state of the synaptic transmission was assessed using the methodology of the loss of righting reflex [16]. It was assumed that at a shock temperature, intracellular changes in the content of calcium ions cannot cause a phase transition of neuronal membranes from a liquid crystalline state to a gel or vice versa $[21,22]$. Testing the hypothesis included a comparison of our experimental results with the results of other authors obtained on various models from invertebrates to humans. 


\section{Experimental model and methods Experimental model}

Zebrafish (Danio rerio) was used as a typical ectothermic animal. An advantage of these fishes is an enormous amount of scientific literature and a completely deciphered genome. The nervous system of zebrafish is well characterized and their genome exhibits a high degree of homology with the genome of mammalians; therefore, it is widely admitted that these fishes can serve a useful model for medical and biological investigations [23-26], and in particular, for experimental studies of genetic and physiological mechanisms of stress, depressive behavior [21, 22], and other psychotic pathologies [27-29]. More than 1200 lines of Danio rerio are now available in appropriate genetic centers, as well as more than 10,000 specimens of frozen sperm, including that from more than 200 mutant and transgenic lines [24, 25]. An important advantage of these fishes is their small size, which makes it possible to neglect the temperature gradient across the body width in the experimental studies of the synaptic transmission blockade after a sharp change of the ambient temperature [30]. At the whole organism level the impairment of the synaptic transmission is recorded as a loss of righting reflex. The upper and lower limits for the functioning of the synaptic exocytosis are determined as a heat shock temperature $T_{H}$ and a cold shock temperature $T_{C}$, respectively. All parameters of the experiment were carefully maintained as the susceptibility to stress in zebrafish depends on environmental changes [31].

\section{Loss of righting reflex metodology}

To study the dependence of $T_{H}$ and $T_{C}$ on the temperature of a prolonged acclimation $\mathrm{T}_{\mathrm{A}}$, fishes Danio rerio (size $20-30 \mathrm{~mm}$ ) were acclimated at various temperatures ranging from 9 to $38^{\circ} \mathrm{C}$ for $7-10$ days. The daylight duration was $12 \mathrm{~h}$. Then the fishes were placed into an actively aerated transparent cylindrical $600 \mathrm{~mL}$ vessel with a diameter of about $10 \mathrm{~cm}$. Air bubbles created a vertical flow of water along the axis of the cylinder. Water temperature was set significantly higher or lower than the temperature of the prolonged acclimation. The aeration intensity was adjusted so that in the normal conditions (that is, at any temperature not inducing loss of righting reflex) the fishes could maintain stability in the water flow created by the air bubbles. The temperature, at which the loss of righting reflex was observed within one minute after a sharp change of the ambient temperature, was defined as $\mathrm{T}_{\mathrm{H}}$ or $\mathrm{T}_{\mathrm{C}}[30]$. The recording time (1 min) was chosen on the basis of the fact that within one minute the temperature gradients between water in the test chamber and the fish internal organs disappeared, while the cells' ionic composition and, the more so, the membrane lipid composition remained unchanged. Indeed, in our experiments, at a maximal temperature difference between the test and acclimation chambers of about $10{ }^{\circ} \mathrm{C}$ and a fish body width of $1.5-2.0 \mathrm{~mm}$, the temperature gradients disappeared within tens of seconds. Regardless of the testing results, after the lapse of $1 \mathrm{~min}$ the fish was relocated back from the test chamber to the acclimation chamber with $T_{A}$, the righting reflex recovered within seconds. If the fish retained the mobility in the water flow within $1 \mathrm{~min}$, the temperature in the test chamber was increased by $1{ }^{\circ} \mathrm{C}$, if the heat shock $\left(\mathrm{T}_{\mathrm{H}}\right)$ was tested, or lowered by $1{ }^{\circ} \mathrm{C}$, if the cold shock $\left(\mathrm{T}_{\mathrm{C}}\right)$ was tested. In each experiment, 20 to 50 fishes were used.

In addition, the kinetics of adaptation of fishes to different temperatures was studied. The adaptation kinetics was evaluated by changes in $\mathrm{T}_{\mathrm{H}}$ and $\mathrm{T}_{\mathrm{C}}$ after a sharp change of $T_{A}$. For this purpose, after a prolonged acclimation at fixed temperatures for 5-10 days, fishes were transferred to another acclimation chamber with different temperature. All chambers were aerated. The dependencies of temperatures $\mathrm{T}_{\mathrm{H}}$ and $\mathrm{T}_{\mathrm{C}}$ on the time of adaptation to a new temperature was recorded in the range from 5 min to 5-7 days. Each fish was used in the experiment no more than once a day.

The values of $\mathrm{T}_{\mathrm{H}}$ and $\mathrm{T}_{\mathrm{C}}$ and the measurement errors were determined using the Microsoft Office Excel 2007 software on the basis of a mean value and half width of the obtained distribution of the experimental temperatures.

\section{Registration of the thermopreferendum temperature}

If the limits of temperature adaptation determine the range of temperatures in which the organism able to survive, then the temperature of the thermopreferendum is chosen by the organism independently in the presence of a wide choice of temperatures.

The thermopreferendum temperature was determined in a gradient bath $200 \mathrm{~cm}$ long and rectangular section $20 \mathrm{~cm} \times 20 \mathrm{~cm}$, divided into 8 compartments by transparent walls with a holes in the center of about $5 \mathrm{~cm}$ in diameter. All sections were aerated; in the first compartment the temperature was held at $18{ }^{\circ} \mathrm{C}$ and in the eighth compartment, at $32{ }^{\circ} \mathrm{C}$. Fishes Danio rerio with size of $20-30 \mathrm{~mm}$ were placed into a gradient chamber after a 5-day acclimation at $18{ }^{\circ} \mathrm{C}$ or at $32{ }^{\circ} \mathrm{C}$. Individual trajectories of fishes were obtained in separate experiments, in which the influence of the social behavior was excluded [32].

\section{Results}

\section{Heat shock and cold shock}

The dependencies of the heat shock temperature $T_{H}$ and of the cold shock temperature $T_{C}$ on the temperature of the long-term acclimation $\mathrm{T}_{\mathrm{A}}$ are presented in Fig. 1 . 


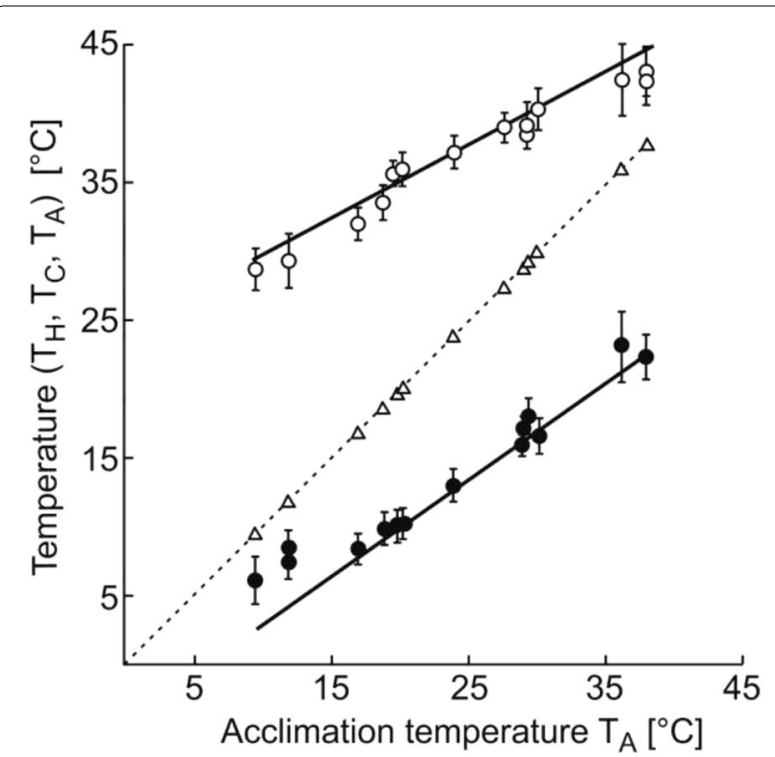

Fig. 1 The dependencies of the heat shock temperature $T_{H}$ and of the cold shock temperature $T_{C}$ on the temperature of the long-term acclimation $T_{A}$ in Danio rerio. Experimental values of $T_{C}$ are shown by filled circles (O); values of $T_{H}$, by open circles (O), and values of $\mathrm{T}_{\mathrm{A}}$, by open triangles $(\Delta)$. Linear regression lines are drawn through temperature values in the range from 20 to $30^{\circ} \mathrm{C}$

The difference between the cold shock temperature $T_{C}$ and the acclimation temperature $\mathrm{T}_{\mathrm{A}}$ varied from $5{ }^{\circ} \mathrm{C}$ to $12{ }^{\circ} \mathrm{C}$, and the difference $\left(\mathrm{T}_{\mathrm{H}}-\mathrm{T}_{\mathrm{A}}\right)$ varied from $5{ }^{\circ} \mathrm{C}$ to $20{ }^{\circ} \mathrm{C}$. Upon return to the vessel with the temperature equal to $\mathrm{T}_{\mathrm{A}}$ the righting reflex recovered within seconds. In the range of definitely tolerable acclimation temperatures, between 20 and $30{ }^{\circ} \mathrm{C}$, both heat-shock temperatures $\mathrm{T}_{\mathrm{H}}$ and cold-shock temperatures $\mathrm{T}_{\mathrm{C}}$ linearly grew with an increase of the acclimation temperature $\mathrm{T}_{\mathrm{A}}$ : $\mathrm{T}_{\mathrm{C}}=0.70 \mathrm{~T}_{\mathrm{A}}-4.12, \mathrm{R}^{2}=0.98, \mathrm{~T}_{\mathrm{H}}=0.53 \mathrm{~T}_{\mathrm{A}}+24.20$, $\mathrm{R}^{2}=0.89$.

The straight line $\mathrm{T}_{\mathrm{A}}=\mathrm{T}_{\mathrm{A}}$ clearly demonstrates that the difference $\mathrm{T}_{\mathrm{A}}-\mathrm{T}_{\mathrm{C}}$ increases with increasing $\mathrm{T}_{\mathrm{A}}$, and the difference $\mathrm{T}_{\mathrm{H}}-\mathrm{T}_{\mathrm{A}}$ decreases. However, the applied approach does not allow to determine the limit values $\mathrm{T}_{\mathrm{C}}=\mathrm{T}_{\mathrm{A}}$ and $\mathrm{T}_{\mathrm{H}}=\mathrm{T}_{\mathrm{A}}$. To identify both the minimum and maximum values of the shock temperatures, the registration of the kinetics of temperature adaptation was used.

\section{Kinetics of temperature adaptation}

The adaptation kinetics of $\mathrm{T}_{\mathrm{H}}$ and $\mathrm{T}_{\mathrm{C}}$ upon sharp change of the water temperature from $20{ }^{\circ} \mathrm{C}$ to $30{ }^{\circ} \mathrm{C}$ are presented in Fig. 2.

Both kinetics are characterized by a smooth transition of $\mathrm{T}_{\mathrm{H}}(\mathrm{O})$ and $\mathrm{T}_{\mathrm{C}}(\boldsymbol{O})$ to a new stationary level. The dependencies of $\mathrm{T}_{\mathrm{H}}(\mathrm{O})$ and $\mathrm{T}_{\mathrm{C}}(\boldsymbol{O})$ in the adaptation time in the logarithmic scale $(\lg (\mathrm{t}))$ were linear. The adaptation

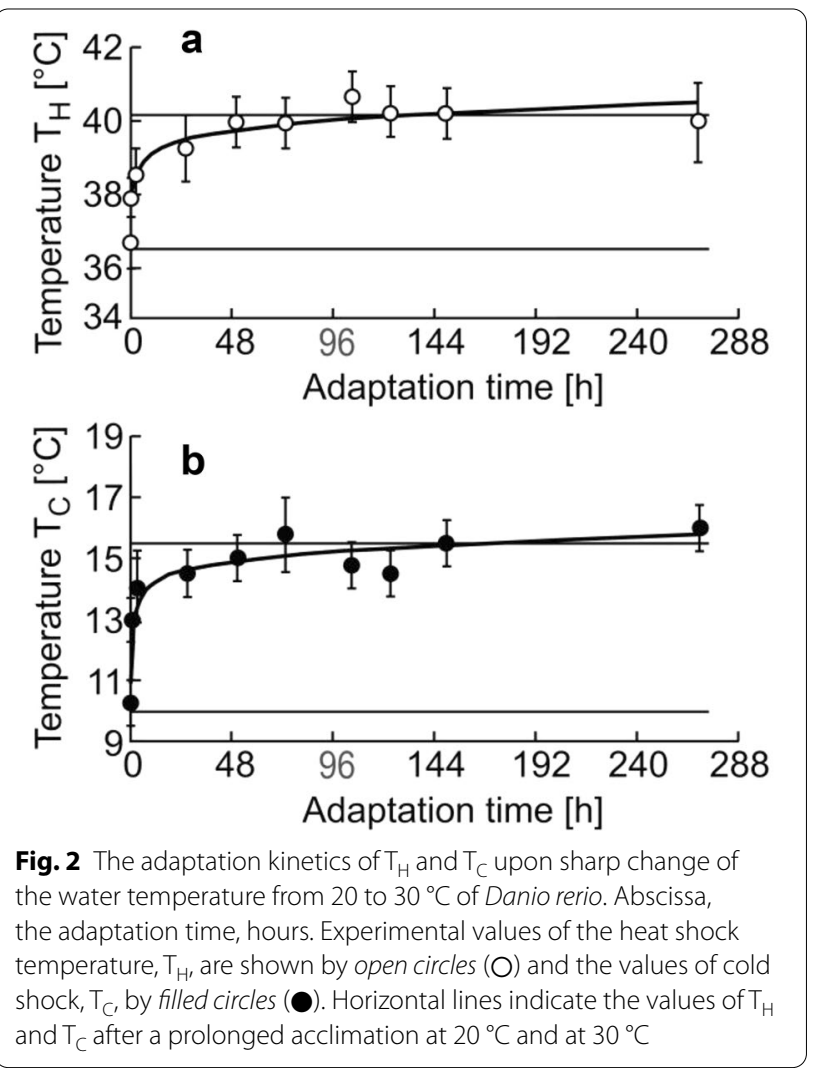

kinetics in the whole viability range of zebrafish is shown in Fig. 3. The experimental results presented in Fig. 3 indicate that upon a sharp change of the water temperature, new stationary values of $\mathrm{T}_{\mathrm{H}}$ and $\mathrm{T}_{\mathrm{C}}$ are established within several days.

Linear dependencies of $T_{H}(O)$ and $T_{H}(\diamond)$ on the logarithm of the adaptation time $\ln (\mathrm{t})$ upon the transfer of fishes in the range of definitely tolerable temperatures, from $20{ }^{\circ} \mathrm{C}$ to $30{ }^{\circ} \mathrm{C}$ and from $30{ }^{\circ} \mathrm{C}$ to $20{ }^{\circ} \mathrm{C}$, are presented in Fig. 3a. Horizontal lines show the stationary values of the thermal shock $\mathrm{T}_{\mathrm{H}}$ equal to $36{ }^{\circ} \mathrm{C}$ during prolonged acclimation at $20{ }^{\circ} \mathrm{C}$ and equal to $40{ }^{\circ} \mathrm{C}$ at $30{ }^{\circ} \mathrm{C}$. The adaptation kinetics of $\mathrm{T}_{\mathrm{C}}(\mathbf{\bullet})$ and $\mathrm{T}_{\mathrm{C}}(\boldsymbol{})$ upon the transfer of fishes from $20^{\circ} \mathrm{C}$ to $30^{\circ} \mathrm{C}$ and from $30{ }^{\circ} \mathrm{C}$ to $20^{\circ} \mathrm{C}$ are presented in Fig. 3b. Horizontal lines indicate stationary values of the cold shock $\mathrm{T}_{\mathrm{C}}$, equal to $11.0{ }^{\circ} \mathrm{C}$ and $16.5^{\circ} \mathrm{C}$ for $20^{\circ} \mathrm{C}$ and $30^{\circ} \mathrm{C}$, respectively. After the temperature shift from $20^{\circ} \mathrm{C}$ to $30^{\circ} \mathrm{C}$ the linear regressions took the form: $\mathrm{T}_{\mathrm{H}}=0.43 \ln (\mathrm{t})+38.01$ at $\mathrm{R}^{2}=0.96$ and $\mathrm{T}_{\mathrm{C}}=0.52 \ln (\mathrm{t})+12.93$ at $\mathrm{R}^{2}=0.98$. When the temperature was shifted back from $30{ }^{\circ} \mathrm{C}$ to $20{ }^{\circ} \mathrm{C}$, the dependencies took the form: $\mathrm{T}_{\mathrm{H}}=-0.48$ $\ln (\mathrm{t})+38.17, \quad \mathrm{R}^{2}=0.91$ and $\mathrm{T}_{\mathrm{C}}=-0.57 \ln (\mathrm{t})+12.31$, $\mathrm{R}^{2}=0.95$.

In the plots presented in Fig. $3 a$ and $b$, changes in $T_{H}$ and $\mathrm{T}_{\mathrm{C}}$ within the first hour after a sharp change in the 


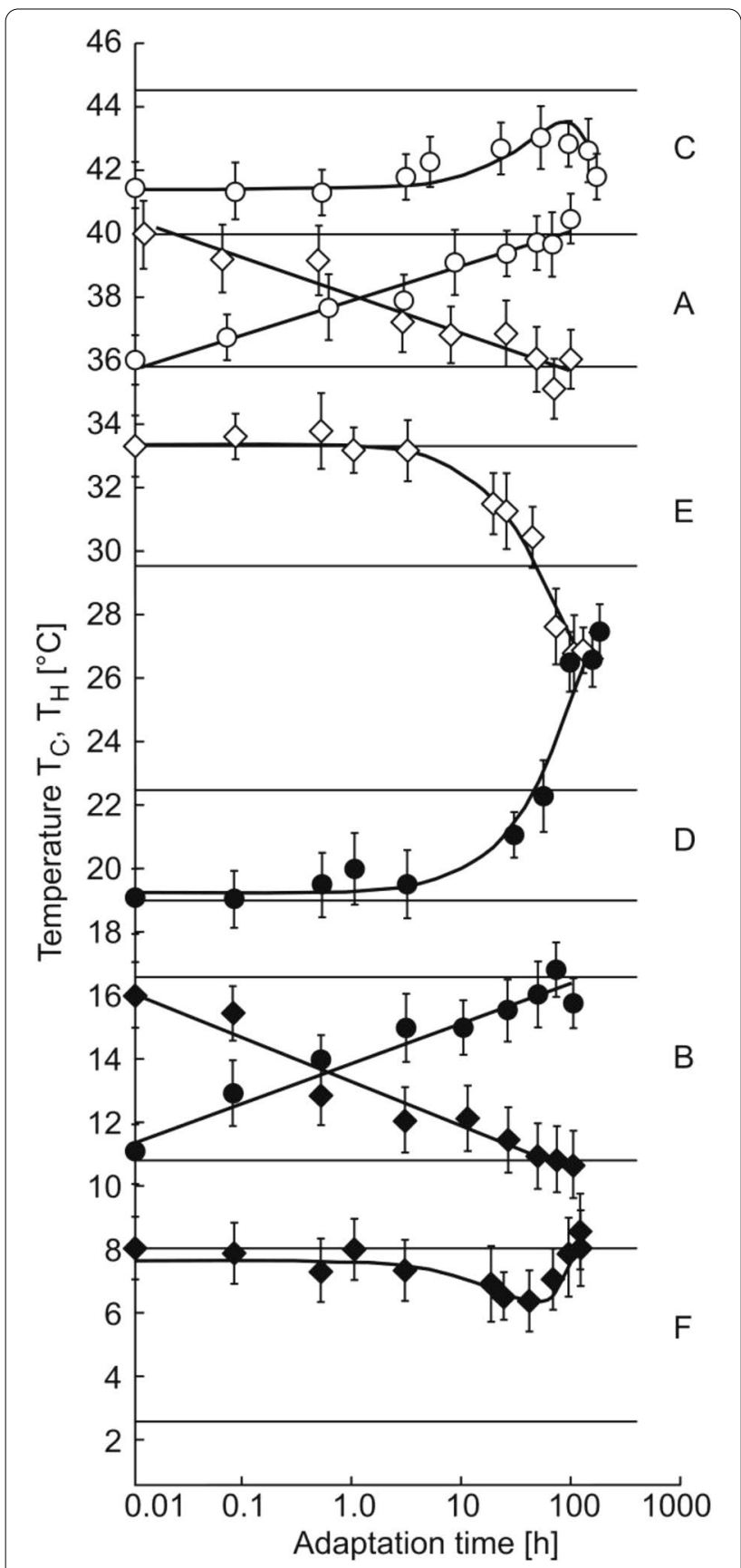

Fig. 3 The kinetics of temperature adaptation of Danio rerio. Abscissa, adaptation time (t) in the logarithmic scale; ordinate, shock temperatures $T_{H}(O), T_{H}(\diamond), T_{C}(\bullet), T_{C}(\diamond)$. Experimental values of $T_{H}$ are shown by open symbols ( $O$ and $\diamond$ ) and values of $T_{C}$, by filled (black) symbols ( and ). The shock temperatures recorded after the transfer of the fishes into water with higher temperatures are designated with circles ( $\mathrm{O}$ and $\mathbf{0}$ ) and shock temperatures recorded after the transfer of the fishes into water with lower temperatures, with diamonds ( $\$ and $\$$ ). Horizontal lines show the stationary values of $T_{H}$ and $T_{C}$ calculated on the basis of linear regression, with regard of the values of shock temperatures in the range from $20^{\circ} \mathrm{C}$ to $30^{\circ} \mathrm{C}$ : $\mathrm{T}_{C}=0.70 \mathrm{~T}_{\mathrm{A}}-4.12, \mathrm{~T}_{\mathrm{H}}=0.53 \mathrm{~T}_{\mathrm{A}}+24.20$. The letters $\mathrm{A}, \mathrm{B}, \mathrm{C}, \mathrm{D}, \mathrm{E}$ and $\mathrm{F}$ indicate the kinetics of adaptation in different temperature ranges temperature amounted about a half of the whole range of the changes in the shock temperatures.

During adaptation to temperatures lower than $20{ }^{\circ} \mathrm{C}$ or higher than $30{ }^{\circ} \mathrm{C}$, the dependencies of shock temperatures $\mathrm{T}_{\mathrm{C}}$ and $\mathrm{T}_{\mathrm{H}}$ on $\mathrm{T}_{\mathrm{A}}$ departed from the linearity mentioned above. The kinetics of $\mathrm{T}_{\mathrm{H}}(\mathrm{O})$ recorded upon the transfer of fishes from $30{ }^{\circ} \mathrm{C}$ to $38^{\circ} \mathrm{C}$ is presented in Fig. 3c. Horizontal lines show stationary values of heat shock temperatures of $40.0^{\circ} \mathrm{C}$ and $44.5^{\circ} \mathrm{C}$, calculated on the basis of the equation $\mathrm{T}_{\mathrm{H}}=0.53 \mathrm{~T}_{\mathrm{A}}+24.2$ for $30{ }^{\circ} \mathrm{C}$ and $38{ }^{\circ} \mathrm{C}$, respectively. The kinetics was low-sloped, maximal value $\mathrm{T}_{\mathrm{H}}(\mathrm{O})=\left(\mathrm{T}_{\mathrm{H}}\right)_{\max }=43{ }^{\circ} \mathrm{C} \mathrm{C}$ was reached only on day 2-4. The kinetics of $\mathrm{T}_{\mathrm{C}}(\mathbf{})$ upon the transfer of a fish from $30{ }^{\circ} \mathrm{C}$ to $38{ }^{\circ} \mathrm{C}$ is shown in Fig. 3d. Horizontal lines indicate calculated stationary values of cold shock temperatures of $19{ }^{\circ} \mathrm{C}$ and $22.5{ }^{\circ} \mathrm{C}$ for $30{ }^{\circ} \mathrm{C}$ and $38^{\circ} \mathrm{C}$, respectively. The $\mathrm{T}_{\mathrm{C}}(\bullet)$ value remained unchanged for 2 days after transferring fishes to $38{ }^{\circ} \mathrm{C}$, and then it began to grow rapidly; within one day the calculated level of $22.5{ }^{\circ} \mathrm{C}$ was reached, and three days later the maximum temperature of cold shock $\left(\mathrm{T}_{\mathrm{C}}\right)_{\max }$, equal to $27^{\circ} \mathrm{C}$ in zebrafish, was reached.

The kinetics of $\mathrm{T}_{\mathrm{H}}(\diamond)$ and $\mathrm{T}_{\mathrm{C}}(\diamond)$ upon the transfer of the fishes from $17{ }^{\circ} \mathrm{C}$ to $9.5^{\circ} \mathrm{C}$ is presented in Fig. 3e and f. Horizontal lines indicate calculated stationary values of heat shock temperatures of $33^{\circ} \mathrm{C}$ and $29.5^{\circ} \mathrm{C}$, as well as cold shock temperatures of $8{ }^{\circ} \mathrm{C}$ and $2.5^{\circ} \mathrm{C}$ for $17{ }^{\circ} \mathrm{C}$ and $9.5{ }^{\circ} \mathrm{C}$, respectively. The temperature $\mathrm{T}_{\mathrm{C}}(\downarrow)$ practically did not change during the first day, and the minimum value of $\mathrm{T}_{\mathrm{C}}(\boldsymbol{)})$ was reached only on days $2-4$ and amounted to $\left(\mathrm{T}_{\mathrm{C}}\right)_{\min }=6.5{ }^{\circ} \mathrm{C}$. During the adaptation to extremal temperatures, $\mathrm{T}_{\mathrm{H}}(\diamond)$ (Fig. 3e) and $\mathrm{T}_{\mathrm{C}}(\boldsymbol{\bullet})$ (Fig. 3d) got beyond the expected level within one day and approached the temperature $\left(\mathrm{T}_{\mathrm{H}}\right)_{\min }=\left(\mathrm{T}_{\mathrm{C}}\right)_{\max }=27{ }^{\circ} \mathrm{C}$. This temperature is of special importance for zebrafish.

\section{Thermopreferendum temperature}

In our experiments in the gradient bath, fish Danio rerio chose the temperature $25-27{ }^{\circ} \mathrm{C}$. The thermopreferendum temperature did not depend on the temperature of the prolonged acclimation either at $\mathrm{T}_{\mathrm{A}}=18{ }^{\circ} \mathrm{C}$ or $\mathrm{T}_{\mathrm{A}}=32^{\circ} \mathrm{C}$, and the decision-taking time did not exceed $1.0-1.5 \mathrm{~h}$. All 10 fish remained at a chosen temperature and moved away for a few minutes not more than by $2-4{ }^{\circ} \mathrm{C}$ during the observation period of at least $4 \mathrm{~h}$.

Figure 4, illustrating the temperature selection by three Danio rerio fish in a gradient bath recorded in separate experiments. Before the experiment, the fish were kept at $18^{\circ} \mathrm{C}$ for 5 days.

At the boundaries of each section of the gradient bath, the water temperature differed from the temperature in the center of the section by $1{ }^{\circ} \mathrm{C}$. The presence of a fish in the $26^{\circ} \mathrm{C}$ section means that the fish avoids water with 


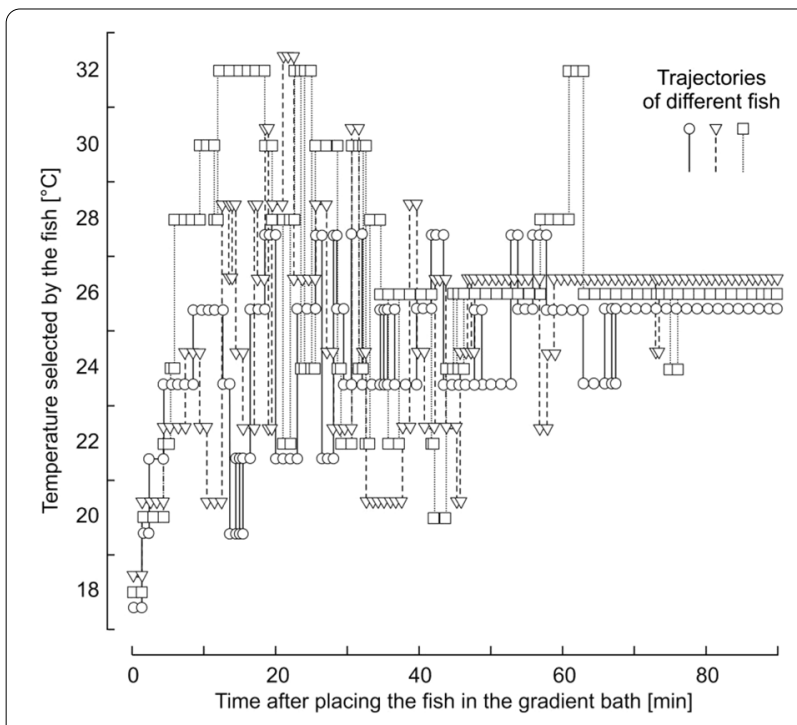

Fig. 4 Temperature selection by three Danio rerio fish in a gradient bath. Abscisa, time after placing the fish in the gradient bath, min; ordinate, temperature selected by the fish, ${ }^{\circ} \mathrm{C}$. Individual trajectories fish movements were obtained in separate experiments, excluding the influence of the flock, and are indicated by different symbols $(\square$ $\triangle, \mathrm{O})$

temperatures above $27{ }^{\circ} \mathrm{C}$ and below $25^{\circ} \mathrm{C}$. This means that the temperature of the thermopreferendum is in the range from 25 to $27^{\circ} \mathrm{C}$. All 10 fish chose the temperature of the thermopreferendum within $1 \mathrm{~h}$ and remained in this section for at least $4 \mathrm{~h}$.

The thermopreferendum temperature $T_{P R}$ for zebrafish in particular, is attractive due to the fact that an acclimation temperature $T_{A}$, equal to the $T_{T P}$, the range of permissible warm temperatures equals to the range of permissible cold temperatures: $\mathrm{T}_{\mathrm{PR}}-\mathrm{T}_{\mathrm{C}}=\mathrm{T}_{\mathrm{H}}-\mathrm{T}_{\mathrm{PR}}$. This means that after a prolonged acclimation at $\mathrm{T}_{\mathrm{A}}=26{ }^{\circ} \mathrm{C}$ the fishes can equally easy overcome both cooling and heating by more than $10{ }^{\circ} \mathrm{C}: 26{ }^{\circ} \mathrm{C}-\mathrm{T}_{\mathrm{C}} \approx \mathrm{T}_{\mathrm{H}}-26{ }^{\circ} \mathrm{C}$. At a temperature of $\mathrm{T}_{\mathrm{A}}$ below $25{ }^{\circ} \mathrm{C}$, the difference between $\mathrm{T}_{\mathrm{H}}$ and $\mathrm{T}_{\mathrm{A}}$ increased, and at a $\mathrm{T}_{\mathrm{A}}$ above $27{ }^{\circ} \mathrm{C}$, it decreased to zero at $\mathrm{T}_{\mathrm{A}}=43{ }^{\circ} \mathrm{C}$. With $\mathrm{T}_{\mathrm{A}}$ more than $27{ }^{\circ} \mathrm{C}$, the difference between $\mathrm{T}_{\mathrm{A}}$ and $\mathrm{T}_{\mathrm{C}}$ increased, and with $\mathrm{T}_{\mathrm{A}}$ less than $25^{\circ} \mathrm{C}$, the difference between $\mathrm{T}_{\mathrm{A}}$ and $\mathrm{T}_{\mathrm{C}}$ decreased to zero at $\mathrm{T}_{\mathrm{A}}=6.5^{\circ} \mathrm{C}$. This means that $\mathrm{T}_{\mathrm{PR}}$ is the most comfortable and safest temperature for Danio rerio. These results are a scientifically based definition of a thermal preferendum.

\section{The viability polygon}

The viability polygon for Danio rerio presented in Fig. 5 is constructed on the basis of the linear dependencies of $\mathrm{T}_{\mathrm{C}}$ and $\mathrm{T}_{\mathrm{H}}$ on $\mathrm{T}_{\mathrm{A}}$ in the $\mathrm{T}_{\mathrm{A}}$ range from 20 to $30^{\circ} \mathrm{C}$. The values of $\mathrm{T}_{\mathrm{H}}$ and $\mathrm{T}_{\mathrm{C}}$ at $20{ }^{\circ} \mathrm{C}$ and $30{ }^{\circ} \mathrm{C}$ are connected by direct

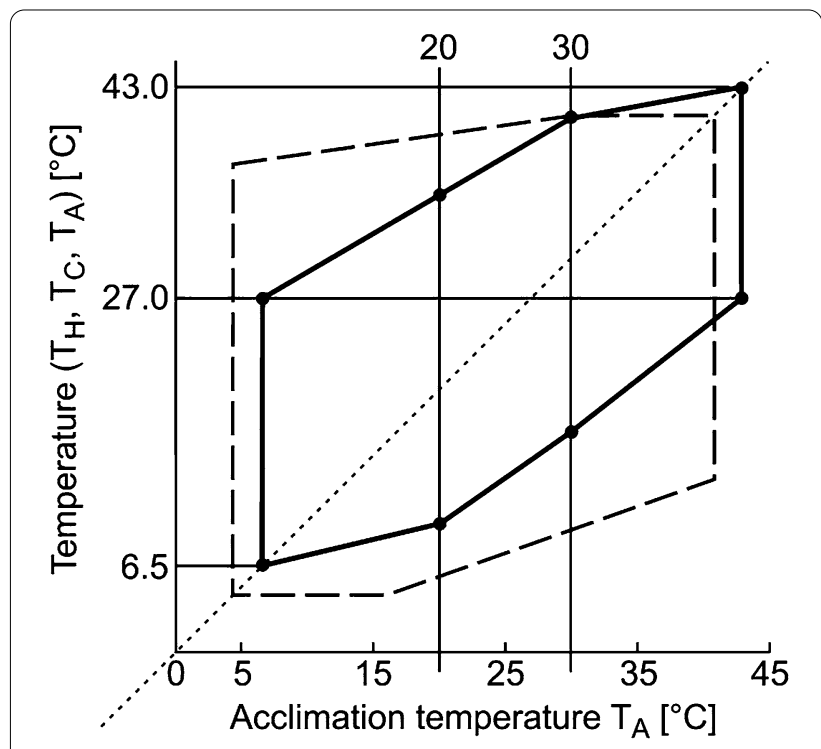

Fig. 5 Comparison of the viability polygon obtained for Danio rerio by means of the loss of righting reflex methodology (solid line) and the polygon of tolerable temperatures obtained by the methodology of the critical maximal and critical minimal temperatures (dashed line) [34]. Abscissa, $T_{A}\left[{ }^{\circ} \mathrm{C}\right]$ and ordinate, $T_{H}\left[{ }^{\circ} \mathrm{C}\right], T_{C}\left[{ }^{\circ} \mathrm{C}\right]$ and $T_{A}\left[{ }^{\circ} \mathrm{C}\right]$

lines with the corresponding values obtained at extremal temperatures $\left(\mathrm{T}_{\mathrm{C}}\right)_{\min }=6.5^{\circ} \mathrm{C}$ and $\left(\mathrm{T}_{\mathrm{H}}\right)_{\max }=43{ }^{\circ} \mathrm{C}$.

It should be noted that the linear dependence of $\mathrm{T}_{\mathrm{H}}$ on $\mathrm{T}_{\mathrm{A}}$, obtained on the basis of the experimental results in the $\mathrm{T}_{\mathrm{A}}$ range from 20 to $30{ }^{\circ} \mathrm{C}$, adequately describes all the results for $\mathrm{T}_{\mathrm{H}}$ in a wider range, from 7 to $30{ }^{\circ} \mathrm{C}$. Similarly, a linear dependence of $\mathrm{T}_{\mathrm{C}}$ on $\mathrm{T}_{\mathrm{A}}$, obtained for a range from 20 to $30^{\circ} \mathrm{C}$ adequately describes the results in the $\mathrm{T}_{\mathrm{A}}$ range from 20 to $43{ }^{\circ} \mathrm{C}$. Of interest is the fact that the range of tolerable temperatures from 20 to $30^{\circ} \mathrm{C}$ lays halfway between the extremal values of $\mathrm{T}_{\mathrm{A}}:\left(20^{\circ} \mathrm{C}-7^{\circ} \mathrm{C}\right)$ $\approx\left(43-30{ }^{\circ} \mathrm{C}\right)$.

\section{Discussion}

\section{Heat shock and cold shock}

In the in vivo behavioral experiments presented in our work, the impairment of coordination and mobility of the fish was recorded under extreme changes in body temperature equal to the ambient temperature. Previously, it was shown that the violation of cyclic changes in membrane fluidity caused by a sharp increase or decrease in ambient temperature will lead to the termination of synaptic transmission, which can be recorded by the loss of the righting reflex [30]. Impaired coordination unequivocally indicates impaired nerve conduction, in particular from the optic receptor to the muscle. Indeed, disturbances in neural conduction not only in the brain, but also in peripheral neurons can cause a loss of equilibrium in the Atlantic cod Gadus morhua [33] Considering 
that each cycle of synaptic exocytosis includes reversible phase transitions of lipids of the presynaptic membrane due to entry and subsequent removal of calcium ions from the presynaptic terminal $[5,6]$, as well as the temperature dependence of coordination disorders [30], it can be stated that the temperature, at which loss of coordination is recorded is the temperature of the phase transition of the lipid-protein complex of the synaptic membrane. At a temperature of heat shock, the membrane remains in a state of liquid crystal, at a temperature of cold shock in a state of gel, and reversible phase transitions of lipids of a presynaptic membrane with changes in intracellular calcium are impossible. At the body level, this condition is recorded as a loss of righting reflex [30].

The conducted experiments confirmed the known linear dependence of critical temperatures (maximum and minimum) on the temperature of the long-term acclimation in the range from $20{ }^{\circ} \mathrm{C}$ to $30{ }^{\circ} \mathrm{C}$ [30, 34]. It is noteworthy that even minor deviations from definitely tolerable temperatures between $20{ }^{\circ} \mathrm{C}$ and $30{ }^{\circ} \mathrm{C}$ evoked shock reactions in fish Danio rerio. Shock proteins expressed both in cold and heat stress were found not only in humans but also in various species of fish, including zebrafish [35]. With a slight increase in temperature in zebrafish, the expression of hsp70 mRNA can increase tenfold, however, the expression of the HSP70 protein increases only at potentially harmful temperatures [36]. Heat shock proteins are expressed in zebrafish at $33^{\circ} \mathrm{C}$ as early as $1 \mathrm{~h}$ after the temperature rise [36, 37]. Exposure of zebrafish to $18{ }^{\circ} \mathrm{C}$ for $4 \mathrm{~h}$ caused a cold stress, an increase in the content of $29 \mathrm{mRNA}$, a decrease in the content of $26 \mathrm{mRNA}$, an increase in the activity of 908 genes encoding proteins, and a decrease in the activity of 468 genes encoding proteins [38]. Note that two-thirds of the recorded range of vital activity of zebrafish Danio rerio (Fig. 4) lies in the region of extreme temperatures leading to the activation of stress mechanisms.

\section{Kinetics of temperature adaptation}

Adaptation to a new ambient temperature is accomplished by regulatory reactions altering the membrane fluidity. In the frames of our notions $[5,6,30]$, these processes are related with changes of intracellular $\mathrm{Ca}^{2+}$ concentration $[14,15]$ and expression of genes responsible for the processes determining the lipid composition of presynaptic membrane and synaptic vesicles [35, 37, 39]. Our experiments (Fig. 3) showed that a change in membrane fluidity occurs within a few days after being placed in an environment with a new temperature. This means that the composition of the lipid and protein components of the membrane is continuously changing for at least this time.
It was shown earlier [40-42] that new values of membrane potential and intracellular concentrations of inorganic ions were established within one hour after the switching off of the active transport. In particular, in human fibroblasts incubated in the presence of $1 \mu \mathrm{M}$ ouabain for $1 \mathrm{~h}$, membrane potential decreased from 50 to $-10 \mathrm{mV}[41,42]$. Calculations on the model system showed that such depolarization can cause an increase in the intracellular $\mathrm{Ca}^{2+}$ concentration from $10^{-4}$ to $10^{-1} \mathrm{mM}$, which is close to the increase of the intracellular $\mathrm{Ca}^{2+}$ concentration during the action potential or upon cooling by $10-15^{\circ} \mathrm{C}[14,15]$. This means that new values of the membrane potential and ionic concentrations are established within tens of minutes.

Considering that the processes of the membrane lipid composition change may take a few days $[35,37,39]$, it can be expected that the changes in $\mathrm{T}_{\mathrm{H}}$ and $\mathrm{T}_{\mathrm{C}}$ within the first hour after the temperature change are determined only by the current concentration of the intracellular $\mathrm{Ca}^{2+}$. In all plots (Fig. 3a and b), changes of $\mathrm{T}_{\mathrm{H}}$ and $\mathrm{T}_{\mathbf{C}}$ within the first hour after the sharp shift of the temperature amounted about a half of the whole range of the shock temperature changes and apparently were mostly determined by changes of the intracellular $\mathrm{Ca}^{2+}$ concentration $[14,15]$.

During adaptation to extremal high temperatures $30{ }^{\circ} \mathrm{C} \leq \mathrm{T}_{\mathrm{A}} \leq 38^{\circ} \mathrm{C}$, changes of the intracellular $\mathrm{Ca}^{2+}$ concentration did not seem to occur, but the impairment of the mechanisms responsible for the synthesis or incorporation into the membranes of the long-chain hard-melting lipids was recorded, and non-selective mechanism of the removal and utilization of lipids was functioning. The increase in $\mathrm{T}_{\mathrm{C}}(\mathbf{O})$ and $\mathrm{T}_{\mathrm{H}}(\mathrm{O})$ observed over several days (Fig. 3d, e) is apparently the result of an increase in the phase transition temperature of the remaining part of the membrane lipids.

If the mechanism of the lipid removal and utilization was functioning, then a decrease in $\mathrm{T}_{\mathrm{H}}(\diamond)$ to the level of $27{ }^{\circ} \mathrm{C}$ and a decrease in $\mathrm{T}_{\mathrm{C}}(\downarrow)$ to $6.5^{\circ} \mathrm{C}$, which was observed within a few days (Fig. 3e and F), can be explained by a decrease in the phase transition temperature of the remaining part of the membrane lipids $[5,6]$. It is of note that upper limits of the thermal niche of the fishes are very sensitive to the water hypoxia [43], however, in our experiments all aquariums with fishes were actively aerated.

It is important to note that recorded motor impairments are easily reversible. After the fish return to the vessel with a long acclimation temperature, mobility and coordination are restored within a few seconds. Note that if the characteristic times of membrane phase transitions, with regard of the establishment of the ambient temperature in the synapse region, do not exceed tens of seconds 
[30], then even the change in the content of intracellular ions - a process inevitably accompanying temperature changes-has characteristic times of the order of tens of minutes [40-42].

Gene expression after a change in temperature develops in the fish Danio rerio $[37,38]$ and Carassius auratus [44] during the first $4 \mathrm{~h}$, and adaptation changes in lipid-protein complexes of synaptic membranes take tens of hours (Figs. 2 and 3). This means that the coordination disorder during a sharp change in temperature is exclusively associated with the absence of phase transitions of the membranes, which leads to the impairment of nerve conduction. An alternative assumption of impaired fusion and rupture of any other cell membranes, for example, of vascular endothelial cells, which affects many metabolic parameters, is beneath criticism, because such effects cannot be develop and disappear within a few seconds.

Long-term exposure to extreme temperatures below $10{ }^{\circ} \mathrm{C}$ or above $38{ }^{\circ} \mathrm{C}$ in our experiments was deleterious for a part of the population. Recall that in our experiments we used young fish $20-30 \mathrm{~mm}$ long, and such fish can tolerate extreme temperatures better than larvae or adults [45]. Fishes refused food, appeared sluggish and exhausted; abdomen was retracted, and a spinal curvature was observed. In particular, at $38{ }^{\circ} \mathrm{C}$ half of the population died out within 3 days. However, the surviving fishes could tolerate the temperature $41^{\circ} \mathrm{C}-42{ }^{\circ} \mathrm{C}$ for several days. A similar pattern was observed at extremely cold temperatures. It is noteworthy that the metabolism activity at $20{ }^{\circ} \mathrm{C}$ is definitely higher than at $10{ }^{\circ} \mathrm{C}$, but fasting for several days at $20^{\circ} \mathrm{C}$ did not have a significant impact on the fishes' habitus. It seems likely that the observed processes are related with disturbances in the lipid metabolism. In normal conditions, the main oxidation substrates in fishes are aminoacids, carbohydrates, and fatty acids. During adaptation to extremal temperatures in the conditions of a high $\mathrm{O}_{2}$ content, all ectotherms including fishes actively utilize not only lipids of the cell membranes [46] but also use lipids from fat deposits in liver and muscles [47]. It has been shown in early works that the mechanisms of interaction of lipid and protein components of cell membranes are similar in a wide variety of organisms from yeast to mammals [46, 48].

\section{Reversible phase transitions}

The viability polygon for Danio rerio (Fig. 5) suggests that the temperature of the phase transition of the most hard-melting lipid-protein composition with a 1000 -fold increase in $\left[\mathrm{Ca}^{+2}\right]$ is reduced by $\left(43{ }^{\circ} \mathrm{C}-27{ }^{\circ} \mathrm{C}\right)=16{ }^{\circ} \mathrm{C}$, and the temperature of the phase transition of the most low-melting lipid-protein composition with an increase in $\left[\mathrm{Ca}^{+2}\right]$ decreases by $\left(27-6{ }^{\circ} \mathrm{C}\right)=21^{\circ} \mathrm{C}$. Accordingly, the temperature ranges of the phase transition are different and depend on the intracellular activity of $\mathrm{Ca}^{+2}$ ions. The range of temperatures of the phase transition in the lipidprotein composition at a high calcium concentration near $\left[\mathrm{Ca}^{+2}\right]>10^{-1} \mathrm{mM}$ is wider than the temperature range in a calcium-free medium at $\left[\mathrm{Ca}^{+2}\right]<10^{-4} \mathrm{mM}$. The ratio of the intervals between the temperature of the thermopreferendum and the extremely high and extremely low temperatures can be estimated as 1.3.

In compliance with the notion of the reversible phase transitions of lipids of the presynaptic membrane in the process of the synaptic exocytosis $[5-7,30]$, it can be said that:

- The range of the phase transition temperatures of lipids of the presynaptic membrane with calcium content below $10^{-4} \mathrm{mM}$ extends from $27{ }^{\circ} \mathrm{C}$ to $42{ }^{\circ} \mathrm{C}$ and amounts about $15^{\circ} \mathrm{C}$.

- The range of the phase transition temperatures of lipids of the presynaptic membrane with calcium content above $10^{-1} \mathrm{mM}$ extends from $6.5^{\circ} \mathrm{C}$ to $27^{\circ} \mathrm{C}$ and is about $20^{\circ} \mathrm{C}$.

This means that a temperature decrease by $15-20{ }^{\circ} \mathrm{C}$ is equivalent to a 1000 -fold increase in the intracellular calcium concentration. These results qualitatively correspond to the theoretical estimates made on the simplest model of the cell ionic-osmotic homeostasis with an account of the activity of the Na,K-APTase and Na-Caexchanger $[14,15]$. The model predicts that at the activation energy for the ionic transport of the order of $30 \mathrm{kcal} /$ mole, a cell with a membrane potential of about $60 \mathrm{mV}$ at $37^{\circ} \mathrm{C}$ after cooling to $26^{\circ} \mathrm{C}$, it is depolarized by $10 \mathrm{mV}$ and increases the content of intracellular calcium from $10^{-4} \mathrm{mM}$ to $10^{-2} \mathrm{mM}$, and a cell with membrane potential of $-60 \mathrm{mV}$ at $26^{\circ} \mathrm{C}$ after cooling to $7{ }^{\circ} \mathrm{C}$, is depolarized by $20 \mathrm{mV}$ and increases the content of intracellular calcium from $10^{-4} \mathrm{mM}$ to $10^{-1} \mathrm{mM}$. These dependencies are analyzed in detail in works $[14,15]$ that provide formulas and specific graphical dependencies.

\section{Viability polygon}

The obtained viability polygon (Fig. 5) qualitatively coincide with the results obtained for Danio rerio using other methods [34]. Traditionally, the polygon of the tolerance temperatures was limited by the values of the critical heat maximum Ctmax and critical cold minimum Ctmin obtained for a given fish species at different values of acclimation temperature $\mathrm{T}_{\mathrm{A}}$ [34]. Determination of Ctmax implies determination of the maximal temperature, at which the fish subjected to constant linear 
increase in the water temperature remains alive after the return to the temperature of preliminary return to the temperature of the preliminary long-term acclimation, $\mathrm{T}_{\mathrm{A}}$. Method of critical temperatures requires determination of temperatures in an immediate proximity of the temperature of the physiological death, which depends both on $\mathrm{T}_{\mathrm{A}}$ and on the speed of the temperature change and even on the housing conditions of the parents $[49,50]$. Maximal differences between the values of Ctmax [34] and $\mathrm{T}_{\mathrm{H}}$ [30] are observed at $\mathrm{T}_{\mathrm{A}}$ below $27{ }^{\circ} \mathrm{C}$ and between temperature Ctmin [34] and $\mathrm{T}_{\mathbf{C}}[30]$, at $\mathrm{T}_{\mathrm{A}}$ above $27^{\circ} \mathrm{C}$. The viability range determined by the methodology of loss of righting reflex [30], stretched from $6{ }^{\circ} \mathrm{C}$ to $43{ }^{\circ} \mathrm{C}$, and the range of tolerable temperatures [34] obtained by the critical temperature method, from 4.5 to $42.0^{\circ} \mathrm{C}$. Main differences between values of Ctmax and $\mathrm{T}_{\mathrm{H}}$ can be explained by incorrect determination of the temperature of physiological death. At temperatures higher than $\mathrm{T}_{\mathrm{H}}$ but lower than Ctmax, the excitation propagation through the synapse is not possible [5-7, 30] and the nervous system of the organism is not able to accomplish coordination of organs and tissues, although the organs and tissues still can function independently at this temperature for some time. Similarly for temperatures lower than $\mathrm{T}_{\mathbf{C}}$ but higher Ctmin.

In the natural area of distribution in India and Bangladesh, fishes Danio rerio prefer brooks, lakes, ponds, and rice fields $[51,52]$. The water temperature in these reservoirs generally ranges from $16.5^{\circ} \mathrm{C}$ to $34.0{ }^{\circ} \mathrm{C}$ [53]. Minimal temperature of $12.3^{\circ} \mathrm{C}$ was recorded in a brook and maximal temperature of $38.6{ }^{\circ} \mathrm{C}$, in a rice field $[51,52]$. This means that the fishes are able to live at these temperatures for several hours or even days, and when possible, can leave the area of extremal temperatures and gather in the area with temperature between 20 and $30^{\circ} \mathrm{C}$.

Note that any living system emits heat and that the temperature of the fish brain in our experiments is higher than the water temperature, but not more than by $1.0^{\circ} \mathrm{C}$. However, when considering the results of other researchers, one should expect that the values of the limiting temperatures will be underestimated by several degrees. This is because brain temperature of Danio rerio recorded in our experiments and body surface temperature recorded in most other studies can differ by several degrees.

\section{Thermopreferendum temperature}

In our gradient bath experiments, the thermal preferential temperature for zebrafish has been shown to be between 25 and $27{ }^{\circ} \mathrm{C}$. This temperature of $28^{\circ} \mathrm{C}$ is optimal for the cultured zebrafish embryonic cell line [54]. At this temperature, the current density in the $\mathrm{Na}^{+}$channels of zebrafish myocytes and the rate of development of the action potential were similar to those in human heart myocytes at $37{ }^{\circ} \mathrm{C}$ [55]. The optimum temperature for other fish species living at a wide range of temperatures, in particular for Lophiosilurus alexandri [56] or Nile tilapia [57], is also $28^{\circ} \mathrm{C}$. Furthermore, the temperature of $25 \pm 2{ }^{\circ} \mathrm{C}$ is a thermopreferendum for frogs (Rana esculenta) [58]. The optimal metabolic rate and the maximal rate of larva formation in nematode Caenorhabditis elegans [59], the maximal regeneration rate in planaria Girardia tigrina [60], the maximal mobility in planaria Schmidtea mediterranea [61] are in the same temperature range from 25 to $27^{\circ} \mathrm{C}$.

It was shown in our experiments (Fig. 3), that the temperature of the thermopreferendum $\mathrm{T}_{\mathrm{PR}}$ is equal to the minimum value of the heat shock temperature $\left(\mathrm{T}_{\mathrm{H}}\right)_{\min }$ and the maximum value of the cold shock temperature $\left(\mathrm{T}_{\mathrm{C}}\right)_{\max }$, which corresponds to the phase transition temperature of the most hard-melting lipid-protein composition in a calcium-containing medium and the most low-melting lipid-protein composition in a calcium-free medium. It means that the revealed viability range for zebrafish $6{ }^{\circ} \mathrm{C}$ to $43{ }^{\circ} \mathrm{C}$ is employed by an overwhelming majority of living organisms found in middle latitudes.

It is difficult to explain, but interestingly the thermoneutral zone, in which the heating rate is equal to the rate of heat release into the environment, and the metabolic rate and substrate consumption are minimal, is located in the temperature range from 25.5 to $28{ }^{\circ} \mathrm{C}$ for both humans and mice [62-64], which coincides with the thermal preferendum for zebrafish.

\section{Arctic and tropical organisms}

In arctic fish Salvelinus alpinus, living at $10-11{ }^{\circ} \mathrm{C}$, the oxygen consumption and hydrogen peroxide production by mitochondria almost doubles at temperatures above $20{ }^{\circ} \mathrm{C}$ [65]. This temperature can be considered extreme for this species of fish. The ratio of the intervals between the temperature of the thermopreferendum and the highest and lowest shock temperatures equals to 1.3. According to our notion, the thermopreferendum temperature for this species is $\mathrm{T}_{\mathrm{PR}} \approx 11-12{ }^{\circ} \mathrm{C}$, maximal temperature is about $20^{\circ} \mathrm{C}$, and a minimal temperature of the lipid phase transition is not lower than $5{ }^{\circ} \mathrm{C}$. Similarly, for a cold-water trout Salvelinus namaycush, living at $8-10^{\circ} \mathrm{C}$, a decrease of the maximal rate of metabolism and a dramatic reduction in the metabolic recovery rate was observed at temperatures above $19^{\circ} \mathrm{C}[66]$.

A tropical tilapia Alcolapia grahami from the lake Magadi (Kenya) lives in rapid stream sources with water temperature of up to $43^{\circ} \mathrm{C}$. The value of the critical heat maximum Ctmax, measured according to the methodology of critical temperatures [34], was $45.6{ }^{\circ} \mathrm{C}$ for this population [67]. Considering that at temperatures above $43{ }^{\circ} \mathrm{C}$ the tertiary and quaternary structure 
of many proteins is violated $[68,69]$, these results should be treated with caution. If an upper temperature limit is taken as $43{ }^{\circ} \mathrm{C}$ and thermopreferendum, as $37{ }^{\circ} \mathrm{C}$, then a lower temperature limit, in analogy with mammalians $[70,71]$, will amount about $30{ }^{\circ} \mathrm{C}$. The metabolism rate measured in these tilapias, exceeds the parameters ever recorded in ectotherms and lays within the basic range of metabolic rates of small mammals [67]. Note that the considered species live in narrow temperature ranges below $15^{\circ} \mathrm{C}$.

\section{Ectothermes and endothermes}

The majority of mammalians and birds maintain the temperature of the visceral organs, such as brain and heart, considerably higher than the ambient temperature. To minimize the heat loss, their bodies are covered with hair or feathers. However, in different periods of life these organisms can lower the metabolic rate and, consequently, the body temperature. During the diurnal rest period, the metabolism rate estimated by oxygen consumption, in most mammalians decreases by about $20 \%$ and a body temperature, by $0.5-2.0^{\circ} \mathrm{C}$. In birds, metabolism rate can decline by $30 \%$, and a light circadian hypothermia can reach $4.0{ }^{\circ} \mathrm{C}$. Furthermore, a considerable number of mammalian and birds can come into a much more prolonged periods of hypometabolism and hypothermia [72]. Assuming that the thermopreferendum temperature in mammalians is $36-38{ }^{\circ} \mathrm{C}$ and the upper limit is $43{ }^{\circ} \mathrm{C}$, then, considering that the temperature interval ratio is close to 1,0 , we can expect that the lower temperature limit will be about $30{ }^{\circ} \mathrm{C}$. This temperature is a low temperature limit recorded in many mammalian species; in particular, American black bear Ursus americanus during seasonal hibernation reversibly cools down to $30{ }^{\circ} \mathrm{C}$ in the circadian cycles lasting many days [70, 71]. In a closely related species, brown bear Ursus arctos, body temperature drops down to $6{ }^{\circ} \mathrm{C}$ and in the interbout arousal increases up to $30^{\circ} \mathrm{C}$ [73].

Winter hibernation in many hibernators, including rodents, bats, lemurs, marsupials, hedgehogs, and brown bears (Ursus arctos) consists of a series of multi-day periods of catalepsy alternating with arousal periods. During catalepsy lasting 10-20 days, the body temperature is about $5-7{ }^{\circ} \mathrm{C}$ and during arousal lasting $1-2$ days, the body temperature grows up to $30{ }^{\circ} \mathrm{C}$ [71, 72, 74]. In this hypometabolic state at $30{ }^{\circ} \mathrm{C}$, in a brown bear Ursus arctos the metabolic activity judged by the oxygen consumption is 4 times lower than the metabolic activity in summer. The creation of similar hypometabolic state during prolonged surgical operations or under conditions of cranio-cerebral trauma in humans may turn very helpful [20].
The brain temperature of many organisms living in mid-latitudes easily varies in the range from 6 to $43{ }^{\circ} \mathrm{C}$; the brain temperature of cold-water organisms ranges from 6 to $20^{\circ} \mathrm{C}$, and the brain temperature of most mammals and birds can vary from 30 up to $43{ }^{\circ} \mathrm{C}$. This means that living organisms are able to exist in each of three temperature ranges, which differ in the mechanisms of synthesis, incorporation and utilization of membrane lipids. At the same time, the area of the viability polygon for cold-water species or for endothermic organisms, including humans, is 6-8 times less than the maximum possible area obtained for zebrafish in our experiments.

\section{Enzymatic activity}

It is noteworthy that the survival range evaluated on the basis of the phase transition temperatures of lipids coincide with the functional activity ranges for most enzymes. The activities of all enzymes decrease upon cooling, and growing density of water at low temperatures, reaching maximum at $3-6{ }^{\circ} \mathrm{C}$, favors the enzyme blockade. At these temperatures the metabolic activity virtually stops $[68,75]$. At temperatures higher than $43{ }^{\circ} \mathrm{C}$, the tertiary and quaternary structure of proteins is impaired, and this determines the upper limit of the viability range $[68,69]$.

The presented experimental results indicate that the upper temperature limit in cold-water fish $[65,66]$ and the lower temperature limit in some warm-water fish [67], mammals and birds [72-74, 76] are determined only by the phase transition temperature of membrane lipidprotein compositions, and not by a blockade of enzymatic activity.

\section{Exclusive integral parameter}

At the cellular and brain levels, there are numerous complex signaling mechanisms. However, a violation in the processes of coordination of the activity of different muscles of the fish body, recorded in our behavioral experiments, unambiguously indicates that signals in the form of sequences of nerve impulses from the visual receptor or from the vestibular apparatus do not enter at least one muscle of the body. The impairment of coordination will be recorded for any disorder in nerve conduction, both at the receptor level, and in various brain structures or at the level of the neuromuscular synapse.

It is important to note that recorded motor impairments are easily reversible. After the fish return to the vessel with a long acclimation temperature, mobility and coordination are restored within a few seconds. Note that if the characteristic times of membrane phase transitions, with regard the time of the establishment of the ambient temperature in the synapse region, do not exceed tens of seconds [30], then even the change in the content of intracellular ions has characteristic times of the order of 
tens of minutes [40-42]. Gene expression after a change in temperature develops in the fish Danio rerio $[37,38]$ or Carassius auratus [44] during the first $4 \mathrm{~h}$, and adaptation changes in lipid-protein complexes of synaptic membranes take tens of hours (see Fig. 3). This means that the coordination disorder during a sharp change in temperature is exclusively associated with the absence of phase transitions of the membranes, which leads to the impairment of nerve conduction. An alternative assumption of impaired fusion and rupture of any other cell membranes, for example, of vascular endothelial cells, which affects many metabolic parameters, is beneath criticism, because such effects cannot be develop and disappear within a few seconds.

Our experiments (see Figs. 1 and 4) showed that any investigated $\mathrm{T}_{\mathrm{A}}$ corresponded to well-defined temperatures of phase transitions $\mathrm{T}_{\mathrm{C}}$ and $\mathrm{T}_{\mathrm{H}}$. Many researchers have long tried to determine the effect of the temperature of long-term acclimation $\mathrm{T}_{\mathrm{A}}$ on the components of lipid membrane [77-85]. It has been shown that adaptation to any $\mathrm{T}_{\mathrm{A}}$ occurs simultaneously with changes in many combinations of lipid and protein components. A comparative analysis of the fatty acid composition of the brain of 17 species of teleost fish obtained from Antarctic, temperate and semi-tropical waters, as well as from rats, turkeys, mammals and birds as typical was carried out. Analysis of the lipid composition of the brain has shown that the relative amounts and ratios of different lipids are the main factors contributing to the maintenance of proper fluidity $[77,78]$. Cold adaptation correlated with an increase in the proportion of unsaturated fatty acids, mainly polyunsaturated fatty acids [77], as well as highly unsaturated phospholipids [79]. The complexity of the analysis of the mechanisms of membrane homeostasis is determined by the presence of many mechanisms that control the properties of the membrane and adjust its composition [80]. Note that some lipids are intermediate products of cellular metabolism and modulators of certain metabolic pathways [81]. Moreover, not only proteins, but also peptides, change the structure of the membrane, creating domains of liquid crystals in the membrane [82], and the activity of membrane enzymes, in turn, depend on the fluidity and lipid composition of the membranes [80]. A change in temperature of the membrane phase transition can occur, for example, when a part of cholesterol is transferred from the plasma membrane to the endoplasmic reticulum [83] or when cholesterol-independent domains are formed under the action of saturated long-chain phospholipids C24 and C16 [84]. It is assumed that temperature adaptation of the brain is associated with the aggregation of monomers of acetylcholinesterase and its dissociation of their tetramers [85]. The task is complicated by the fact that more than 40.000 lipids can be identified [86] and more than 5.000 different membrane proteins [87] were detected in the composition of cell membranes. It is practically impossible to predict the behavior of such a complex system from the standpoint of biochemistry.

The listed facts allow us to state that many variants of lipid and protein components of synaptic membranes can correspond to any specific $\mathrm{T}_{\mathrm{A}}$ value. Moreover, our experiments (Fig. 3) showed that the change in membrane fluidity occurs within a few days after being placed in an environment with a new temperature. This means that the composition of the lipid and protein components of the membrane is continuously changing for at least this time. Many variants of the composition of lipid and protein components of the synaptic membrane seem to depend on the type of organism and on the temperature prehistory (heating or cooling) of the nervous system.

The loss of righting reflex methodology allows us to characterize the state of the membrane using only one parameter. The advantage of our method of recording temperature shock is the possibility of detecting phase transitions of membrane lipids in a behavioral experiment in vivo. We assume that the minimum phase transition temperature of the most low-melting lipid-protein composition at a high calcium concentration does not exceed $7{ }^{\circ} \mathrm{C}$, and the maximum phase transition temperature of the highest-melting lipid-protein composition is $27^{\circ} \mathrm{C}$, which is the minimum phase transition temperature of the most low-melting lipid protein composition in a calcium-free medium. The maximum temperature of the phase transition of the most refractory lipid-protein composition in a calcium-free medium is $43^{\circ} \mathrm{C}$, and at a high calcium concentration it is $27^{\circ} \mathrm{C}$. Mammals, birds, and many organisms from polar or tropical waters live in much narrower temperature ranges.

Apparently, narrow temperature ranges of vital activity correspond to narrower temperature ranges of phase transitions and different values of the thermopreferendum. The phase transition temperature is the exclusive integral parameter characterizing the functional state of membrane lipids.

\section{Conclusions}

The use of a fish Danio rerio and the loss of righting reflex methodology made it possible to determine the limits of temperature adaptation in terms of temperatures of cold shock and heat shock.

It is shown that the experimental values of the temperatures of cold shock and heat shock and the temperature of the thermal preferendum correspond to the temperatures of phase transitions of the lipid-protein composition of the synaptic membrane between the liquid and 


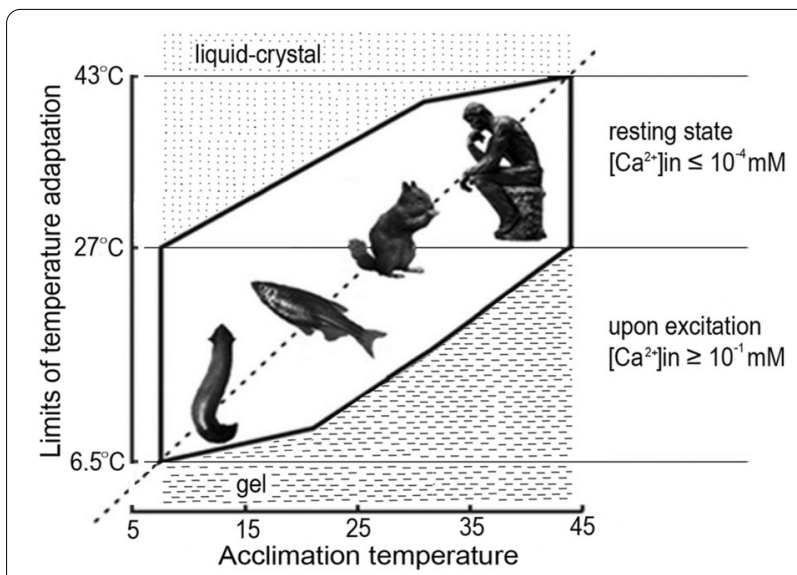

Fig. 6 The limits of temperature adaptation of various organisms. Abscissa, acclimation temperature $\mathrm{T}_{\mathrm{A}}\left[{ }^{\circ} \mathrm{C}\right]$, and ordinate, characteristic constants: $\left(\mathrm{T}_{\mathrm{C}}\right)_{\min }\left[{ }^{\circ} \mathrm{C}\right], \mathrm{T}_{\mathrm{PR}}\left[{ }^{\circ} \mathrm{C}\right]$ and $\left(\mathrm{T}_{\mathrm{A}}\right)_{\max }\left[{ }^{\circ} \mathrm{C}\right]$

solid states. The resulting range of viability coincides with the temperature range in which cellular enzymes function effectively.

The results of our experiments allowed us to give a unified interpretation of fragmentary and disparate experimental results of other researchers. The analysis revealed important characteristic constants that determine the polygon of viability of many organisms: $\left(\mathrm{T}_{\mathrm{C}}\right)_{\min }=7{ }^{\circ} \mathrm{C}$, $\left(\mathrm{T}_{\mathrm{H}}\right)_{\max }=43{ }^{\circ} \mathrm{C}, \mathrm{T}_{\mathrm{PR}}=\left(\mathrm{T}_{\mathrm{C}}\right)_{\max }=\left(\mathrm{T}_{\mathrm{H}}\right)_{\min }=27{ }^{\circ} \mathrm{C}$, as well as the ratio of the intervals between the thermal preferendum and extremely low and extremely high temperatures, which is close to 1.3 . The viability polygon and the ratio of cold shock to heat shock temperature ranges obtained for Danio rerio describe with good accuracy those for the planarian Girardia tigrina, the ground squirrel Sermophilus undulatus, and for Homo sapiens (Fig. 6).

At the genome level, the overwhelming majority of organisms are able to create lipid-protein compositions of synaptic membranes, the melting temperature of which can vary from 7 to $27^{\circ} \mathrm{C}$ in presence of $10^{-1} \mathrm{mM}$ calcium ions and from 27 to $43^{\circ} \mathrm{C}$, in a calcium-free environment. In fish and planarians, this ability is preserved throughout life, while in mammals, including humans, only in early postnatal ontogenesis, and in hibernators this occurs periodically, during seasonal hibernation.

The polygon of the viability of a particular organism is determined not only by the genome, but also by the physicochemical properties of lipids that make up the membrane structures of synaptic endings. The limits of temperature adaptation of any biological species are determined by the temperature range of the functioning of its nervous system.

\section{Abbreviations}

$\mathrm{T}_{\mathrm{A}}$ : Acclimation temperature; $\mathrm{T}_{\mathrm{H}}$ : Heat shock temperature; $\mathrm{T}_{\mathrm{C}}$ : Cold shock temperature; $\left(T_{C}\right)_{\text {min }}$ : Minimum temperature of cold shock; $\left(T_{C}\right)_{\max }$ : Maximum temperature of cold shock; $\left(T_{H}\right)_{\min }$ : Minimum temperature of heat shock; $\left(T_{H}\right)_{\max }$ : Maximum temperature of heat shock; $\mathrm{T}_{\mathrm{TP}}$ : Thermopreferendum temperature.

\section{Acknowledgements}

The authors thank Vlada Avsarkisova (Institute of Molecular Biology and Biophysics, Georgian Academy of Sciences, Georgia) and Emmanuel Le Ray (Centre Hospitalier Victor Dupouy, Argenteuil, France) for the assistance in the experimental work, Dr. Nadezhda Zakharova (Institute of Cell Biology, RAS, Russia) for useful discussion of the obtained results and Dr. Antonina DuninaBarkovskaya (Belozersky Institute of Physico-Chemical Biology, Moscow State University, Russia) for editing and providing language help.

\section{Authors' contributions}

This manuscript was written by KBA. DPK: Conceptualization, Investigation. KBA: Methodology, Investigation, Data curation, Writing — review \& editing. The authors read and approved the final manuscript.

\section{Funding}

I have not received and am not receiving any grant funding for the "Temperature adaptation limits and thermal preferendum" research.

\section{Availability of data and materials \\ All data and materials are available.}

\section{Declarations}

\section{Ethics approval and consent to participate}

All procedures with Danio rerio were performed in accordance with the European Communities Council Directive (November 24, 1986; 86/609/EEC) and the Declaration on humane treatment of animals. The Protocol of experiments was approved by the Commission on Bioethics of the Institute of Theoretical and Experimental Biophysics, Russian Academy of Science.

\section{Consent for publication}

Not applicable.

\section{Competing interests}

Authors have no conflict of interests. This research did not receive any specific grant from funding agencies in the public, commercial, or not-for-profit sectors.

Received: 5 February 2021 Accepted: 18 March 2021

Published online: 06 April 2021

\section{References}

1. Lande $M B$, et al. The relationship between membrane fluidity and permeabilities to water, solutes, ammonia, and protons. J Gen Physiol. 1995;106:67-84. https://doi.org/10.1085/jgp.106.1.67.

2. Ernst $\mathrm{R}$, et al. Homeoviscous adaptation and the regulation of membrane lipids. J Mol Biol. 2016;428:4776-91. https://doi.org/10.1016/j. jmb.2016.08.013.

3. Düzgüneş N, Ohki S. Calcium-induced interaction of phospholipid vesicles and bilayer lipid membranes. BiochimBiophysActa. 1977;467(3):301-8. https://doi.org/10.1016/0005-2736(77)90307-8.

4. Hoekstra D, et al. Agglutination and fusion of globoside GL-4 containing phospholipid vesicles mediated by lectins and calcium ions. Biochemistry. 1985;24(3):565-72. https://doi.org/10.1021/bi00324a00 45.

5. Kharakoz DP. Phase transition in lipids and the problem of homoiothermia. Biofizika. 2000;45(3):569-72.

6. Kharakoz DP. Phase-transition-driven synaptic exocytosis: a hypothesis and its physiological and evolutionary implications. Biosci Rep. 2001;21(6):801-30. https://doi.org/10.1023/a:1015588825142. 
7. Kharakoz DP, et al. A kinetic lattice model of the chain-melting phase transition in lipid membrane: its experimental calibration and physiological implications. Biofizika. 2011;56(5):813-20.

8. Alabi ARA, Tsien RW. Perspectives on kiss-and-run: role in exocytosis, endocytosis, and neurotransmission. Annu Rev Physiol. 2013;75:393-422. https://doi.org/10.1146/annurev-physiol-020911-153305.

9. Liang $\mathrm{K}$, et al. Exocytosis, endocytosis, and their coupling in excitable cells. Front MolNeurosci. 2017;10:109. https://doi.org/10.3389/fnmol. 2017.00109.

10. Cocchi M, et al. Linoleic acid: Is this the key that unlocks the quantum brain? Insights linking broken symmetries in molecular biology, mood disorders and personalisticemergentism. BMC Neurosci. 2017;18(1):38. https://doi.org/10.1186/s12868-017-0356-1.

11. Watanabe $S$, Boucrot E. Fast and ultrafast endocytosis. CurrOpin Cell Biol. 2017;47:64-71. https://doi.org/10.1016/j.ceb.2017.02.013.

12. Han J, et al. The multifaceted role of SNARE proteins in membrane fusion. Front Physiol. 2017;8:5. https://doi.org/10.3389/fphys.2017.00005 (eCollection 2017).

13. Holz RW, Zimmerberg J. Dynamic relationship of the SNARE complex with a membrane. Biophys J. 2019;117(4):627-30. https://doi.org/10. 1016/j.bpj.2019.07.010.

14. Aslanidi $\mathrm{KB}$, et al. A model of ionic osmotic homeostasis in cells upon cooling. DokIAkadNauk. 1994;338(2):251-4.

15. Aslanidi KB, et al. A possible role of cold-induced ionic stress in coldinduced cell death. Membr Cell Biol. 1997;11(1):57-76.

16. Ingram LO, et al. On the relationship between alcohol narcosis and membrane fluidity. Subst Alcohol Actions Misuse. 1982;3(4):213-24.

17. Gee KW, et al. CL 218872 antagonism of diazepam induced loss of righting reflex: evidence for partial agonistic activity at the benzodiazepine receptor. Life Sci. 1983;32(9):1037-40. https://doi.org/10.1016/00243205(83)90936-0.

18. Greizerstein HB. Tolerance to ethanol: effect of congeners present in bourbon. Psychopharmacology. 1977;53(2):201-3. https://doi.org/10. 1007/BF00426493.

19. Soykan T, Haucke V. Synaptic vesicle endocytosis occurs on multiple timescales and is mediated by formin-dependent actin assembly. Neuron. 2017;93(4):854-66. https://doi.org/10.1016/j.neuron.2017.02.011.

20. Choukèr $A$, et al. Hibernating astronauts — science or fiction? PflügersArchiv. Eur J Physiol. 2019;471:819-28. https://doi.org/10.1007/ s00424-018-2244-7.

21. Egan RJ, et al. Understanding behavioral and physiological phenotypes of stress and anxiety in zebrafish. Behav Brain Res. 2009;205(1):38-44. https://doi.org/10.1016/j.bbr.2009.06.022 (Epub 2009 Jun 18).

22. Kyzar EJ, Kalueff AV. Exploring hallucinogen pharmacology and psychedelic medicine with zebrafish models. Zebrafish. 2016;13(5):379-90. https://doi.org/10.1089/zeb.2016.1251.

23. Beliaeva NF, et al. Zebrafish as a model organism for biomedical studie. Biomed Khim. 2010;56(1):120-31. https://doi.org/10.18097/pbmc201056 01120.

24. Geisler R, et al. Maintenance of zebrafish lines at the European Zebrafish Resource Center. Zebrafish. 2016;13(Suppl 1):S19-23. https://doi.org/10. 1089/zeb.2015.1205.

25. Varga ZM, et al. Workshop report: Zebrafish and other fish modelsdescription of extrinsic environmental factors for rigorous experiments and reproducible results. Zebrafish. 2018;15(6):533-5. https://doi.org/10. 1089/zeb.2018.29006.zol.

26. Yang $X$, et al. High-throughput screening in Larval Zebrafish identifies novel potent sedative-hypnotics. Anesthesiology. 2018;129(3):459-76. https://doi.org/10.1097/ALN.0000000000002281.

27. Nguyen $\mathrm{M}$, et al. Aquatic blues: modeling depression and antidepressant action in zebrafish. ProgNeuropsychopharmacolBiol Psychiatry. 2014;55:26-39. https://doi.org/10.1016/j.pnpbp.2014.03.003 (Epub 2014 Mar 19).

28. Stewart AM, et al. Molecular psychiatry of zebrafish. Mol Psychiatry. 2015;20(1):2-17. https://doi.org/10.1038/mp.2014.128 (Epub 2014 Oct 28)

29. Lakstygal AM, et al. Zebrafish models of epigenetic regulation of CNS functions. Brain Res Bull. 2018;142:344-51. https://doi.org/10.1016/j.brain resbull.
30. Aslanidi KB, et al. Temperature shock and adaptation in fish. BiochemBiophysMol Biol. 2008;422:302-3. https://doi.org/10.1134/s16076729080501 28.

31. Marcon M, et al. Environmental enrichment modulates the response to chronic stress in zebrafish. J Exp Biol. 2018;221:jeb176735. https://doi.org/ 10.1242/jeb.176735 (Published 22 February 2018).

32. Tea J, et al. Social stress increases plasma cortisol and reduces forebrain cell proliferation in subordinate male zebrafish (Danio rerio). J Exp Biol. 2019;222:jeb194894. https://doi.org/10.1242/jeb.194894 (Published 24 January 2019)

33. Jutfelt $F$, et al. Brain cooling marginally increases acute upper thermal tolerance in Atlantic cod. J Exp Biol. 2019;222:jeb208249. https://doi.org/ 10.1242/jeb.208249.

34. Lopez-Olmeda JF, Sanchez-Vazquez FJ. Thermal biology of zebrafish (Danio rerio). J Thermal Biol. 2011;36:91-104.

35. Xu K, et al. Genome-wide identification of Hsp70 genes in the large yellow croaker (Larimichthys crocea) and their regulated expression under cold and heat stress. Genes. 2018;9(12):E590. https://doi.org/10.3390/ genes9120590.

36. Mottola G, et al. Hsp70s transcription-translation relationship depends on the heat shock temperature in zebrafish. Comp BiochemPhysiol A Mollntegr Physiol. 2020;240:110629. https://doi.org/10.1016/j.cbpa.2019. 110629 (Epub 2019 Nov 29).

37. Jerônimo R, et al. Thermal stress in Danio rerio: a link between temperature, light, thermo-TRP channels, and clock genes. J Therm Biol. 2017;68:128-38. https://doi.org/10.1016/j.jtherbio.2017.02.009.

38. Hung I.C. et all. MicroRNAs regulate gene plasticity during cold shock in zebrafish larvae. BMC Genomics. 2016;17(1):922. https://doi.org/10.1186/ s12864-016-3239-4.

39. Jacquemyn J, Cascalho A, Goodchild RE. The ins and outs of endoplasmic reticulum-controlled lipid biosynthesis. EMBO Rep. 2017;18(11):1905-21. https://doi.org/10.15252/embr.201643426.

40. Aslanidi $\mathrm{KB}$, et al. Energy cooperation between animal cells during complete blockade of the $\mathrm{Na}+, \mathrm{K}+$-pumps in a part of the cells. DoklAkadNauk SSSR. 1989;305(4):990-3.

41. Potapova TV, et al. Energy transfer via cell-to-cell junctions. Oubain-resistant cells maintain a membrane potential in oubain-sensitive cells. FEBS Lett. 1990;262(1):69-71. https://doi.org/10.1016/0014-5793(90)80156-d.

42. Aslanidi $\mathrm{KB}$, et al. Energetic cooperation via ion-permeable junctions in mixed cell cultures. FEBS Lett. 1991;283(2):295-7. https://doi.org/10.1016/ 0014-5793(91)80612-7.

43. Ern R, et al. Oxygen dependence of upper thermal limits in fishes. J Exp Biol. 2016;219:3376-83. https://doi.org/10.1242/jeb.143495 (Epub 2016 Sep 2).

44. Kim, et al. Identification, tissue distribution and characterization of two heat shock factors (HSFs) in goldfish (Carassius auratus). Fish Shellfish Immunol. 2015;43(2):375-86. https://doi.org/10.1016/j.fsi.2015.01.004

45. Madeira D, et al. Different sensitivity to heatwaves across the life cycle of fish reflects phenotypic adaptation to environmental niche. Mar Environ Res. 2020;162:105192. https://doi.org/10.1016/j.marenvres.2020.105192 (Epub 2020 Oct 13).

46. Los DA, Murata N. Membrane fluidity and its roles in the perception of environmental signals. Biochimica et BiophysicaActa (BBA). 2004;1666(12):142-57. https://doi.org/10.1016/j.bbamem.2004.08.002.

47. Jia $\mathrm{S}$, et al. Amino acids are major energy substrates for tissues of hybrid striped bass and zebrafish. Amino Acids. 2017;49(12):2053-63. https://doi. org/10.1007/s00726-017-2481-7.

48. Nemoto Y, et al. Functional characterization of a mammalian Sac1 and mutants exhibiting substrate-specific defects in phosphoinositide phosphatase activity. J Biol Chem. 2000;275(44):34293-305.

49. Morgan R, et al. Are model organisms representative for climate change research? Testing thermal tolerance in wild and laboratory zebrafish populations. Conserv Physiol. 2019;7(1):Coz036. https://doi.org/10.1093/ conphys/coz036 (eCollection 2019).

50. Ho DH, Burggren WW. Parental hypoxic exposure confers off spring hypoxia resistance in zebrafish (Danio rerio). J ExpBiol. 2012;215(Pt 23):4208-16. https://doi.org/10.1242/jeb.074781.

51. Engeszer RE, et al. Zebrafish in the wild: a review of natural history and new notes from the field. Zebrafish. 2007;4(1):21-39. https://doi.org/10. 1089/zeb.2006.9997. 
52. Arunachalam $M$, et al. Natural history of zebrafish (Danio rerio) in India. Zebrafish. 2013;10(1):1-14. https://doi.org/10.1089/zeb.2012.0803.

53. Spence R, et al. The distribution and habitat preferences of the zebrafish in Bangladesh. J Fish Biol. 2006;69(5):1435-48. https://doi.org/10.1111/j. 1095-8649.2006.01206.x.

54. Airaksinen S, et al. Heat- and cold-inducible regulation of HSP70 expression in zebrafish ZF4 cells. Comp BiochemPhysiol B BiochemMol Biol. 2003;136(2):275-82. https://doi.org/10.1016/s1096-4959(03)00205-7.

55. Haverinen J, et al. Cardiac voltage-gated sodium channel expression and electrophysiological characterization of the sodium current in the zebrafish (Danio rerio) ventricle. ProgBiophysMol Biol. 2018. https://doi. org/10.1016/j.pbiomolbio.

56. Mattioli CC, et al. Response of juvenile Lophiosilurusalexandri to osmotic and thermic shock. Fish PhysiolBiochem. 2020;46(1):51-61. https://doi. org/10.1007/s10695-019-00696-5 (Epub 2019 Aug 17)

57. Nivelle R, et al. Temperature preference of Nile tilapia (Oreochromis niloticus) juveniles induces spontaneous sex reversal. PLoS One. 2019;14(2):e0212504. https://doi.org/10.1371/journal.pone.0212504 (eCollection 2019).

58. Cormarèche-Leydier $M$. The effect of an intraperitoneal injection of capsaicin on the thermopreferendum in the frog (Rana esculenta). PhysiolBehav. 1986;36(1):29-32. https://doi.org/10.1016/0031-9384(86) 90068-5.

59. Ailion $\mathrm{M}$, Thomas JH. Dauer formation induced by high temperatures in Caenorhabditis elegans. Genetics. 2000;156(3):1047-67.

60. Tiras HP, Gudkov SV, Emelyanenko VI, Aslanidi KB. Own chemiluminescence of planarian neoblasts during regeneration. Biofizika. 2015;60(5):975-80.

61. Hammoudi N, et al. Temperature affects the biology of Schmidteamediterranea. Sci Rep. 2018;8(1):14934. https://doi.org/10.1038/ s41598-018-33355-5.

62. Refinetti R, Horvath SM. Thermopreferendum of the rat: inter- and intrasubject variabilities. Behav Neural Biol. 1989;52(1):87-94. https://doi.org/ 10.1016/s0163-1047(89)90194-5.

63. Keijer J, et al. What is the best housing temperature to translate mouse experiments to humans? MolMetab. 2019;25:168-76. https://doi.org/10. 1016/j.molmet.2019.04.001 (Epub 2019 Apr 6).

64. Pallubinsky $\mathrm{H}$, et al. Exploring the human thermoneutral zone - $\mathrm{A}$ dynamic approach. J Therm Biol. 2019;79:199-208. https://doi.org/10. 1016/j.jtherbio.2018.12.014.

65. Christen F, et al. Thermal tolerance and thermal sensitivity of heart mitochondria: Mitochondrial integrity and ROS production. Free RadicBiol Med. 2018;116:11-8. https://doi.org/10.1016/j.freeradbiomed.2017.12. 037.

66. Kelly $\mathrm{NI}$, et al. Ice age fish in a warming world: minimal variation in thermal acclimation capacity among lake trout (Salvelinus namaycush) populations. Conserv Physiol. 2014;2(1):cou025. https://doi.org/10.1093/ conphys/cou025 (eCollection 2014).

67. Wood CM, et al. Mammalian metabolic rates in the hottest fish on earth. Sci Rep. 2016;6:26990. https://doi.org/10.1038/srep26990.

68. Arrigoni C, Minor DL Jr. Global versus local mechanisms of temperature sensing in ion channels. Pflugers Arch. 2018;470(5):733-44. https://doi. org/10.1007/s00424-017-2102-z.

69. Serdyuk I, et al. Methods in molecular biophysics. Cambridge: Cambridge University Press; 2007. p. 1120

70. Toien $\mathrm{O}$, et al. Hibernation in black bears: independence of metabolic suppression from body temperature. Science. 2011;331:906-9. https:// doi.org/10.1126/science.1199435.

71. Hibernation GF. CurrBiol. 2013;23(5):188-93. https://doi.org/10.1016/j.cub. 2013.01.062.
72. Heldmaier G, et al. Natural hypometabolism during hibernation and daily torpor in mammals. RespirPhysiolNeurobiol. 2004;141(3):317-29. https:// doi.org/10.1016/j.resp.2004.03.014.

73. Welinder KG, et al. Biochemical foundations of health and energy conservation in hibernating free-ranging subadult brown bear Ursusarctos. J Biol Chem. 2016;291:22509-23. https://doi.org/10.1074/jbc.M116.742916 (Epub 2016 Sep 8).

74. Geiser F, et al. Torpor and hypothermia: reversed hysteresis of metabolic rate and body temperature. Am J PhysiolRegullntegr Comp Physiol. 2014;307:R1324-9.

75. He X. Thermostability of biological systems: fundamentals, challenges, and quantification. Open Biomed Eng J. 2011;5:47-73. https://doi.org/10. 2174/1874120701105010047.

76. RufT, Geiser F. Daily torpor and hibernation in birds and mammals. Biol Rev CambPhilosSoc. 2015;90(3):891-926. https://doi.org/10.1111/brv. 12137 (Epub 2014 Aug 15).

77. Logue JA, et al. Lipid compositional correlates of temperature-adaptive interspecific differences in membrane physical structure. J Exp Biol. 2000;203(Pt 14):2105-15.

78. Farkas T, et al. Docosahexaenoic acid-containing phospholipid molecular species in brains of vertebrates. Proc Natl AcadSci USA. 2000;97(12):63626. https://doi.org/10.1073/pnas.120157297.

79. Käkelä $R$, et al. Seasonal acclimatization of brain lipidome in a eurythermal fish (Carassius carassius) is mainly determined by temperature. Am J PhysiolRegullntegr Comp Physiol. 2008;294(5):R1716-28. https://doi.org/ 10.1152/ajpregu.00883.2007.

80. de Mendoza D, Pilon M. Control of membrane lipid homeostasis by lipid-bilayer associated sensors: a mechanism conserved from bacteria to humans. Prog Lipid Res. 2019;76:100996. https://doi.org/10.1016/j.plipres. 2019.100996.

81. Chai JF, et al. Associations with metabolites in Chinese suggest new metabolic roles in Alzheimer's and Parkinson's diseases. Hum Mol Genet. 2019. https://doi.org/10.1093/hmg/ddz246.

82. Oliynyk V, et al. Lipid membrane domain formation and alamethicin aggregation studied by calorimetry, sound velocity measurements, and atomic force microscopy. Biophys Chem. 2008;134:168-77. https://doi. org/10.1016/j.bpc.2008.02.004 (Epub 2008 Mar 10).

83. Naito T, et al. Movement of accessible plasma membrane cholesterol by the GRAMD1 lipid transfer protein complex. Elife. 2019;8:e51401. https:// doi.org/10.7554/eLife.51401.

84. Gupta A, et al. Long acyl chain ceramides govern cholesterol and cytoskeleton dependence of membrane outer leaflet dynamics. BiochimBiophysActaBiomembr. 2020;1862(3):183153. https://doi.org/10.1016/j. bbamem.2019.183153 (Epub 2019 Dec 16).

85. Aswani $V$, Trabucco D. Biochemical adaptation in brain Acetylcholinesterase during acclimation to sub-lethal temperatures in the eurythermal fish Tilapia mossambica. Sci Rep. 2019;9(1):19762. https://doi.org/10.1038/ s41598-019-56066-X.

86. Kuo T-C, Tseng YJ. LipidPedia: a comprehensive lipid knowledgebase. Bioinformatics. 2018;34(17):2982-7. https://doi.org/10.1093/bioinforma tics/bty213.

87. Dobson L, et al. The human transmembrane proteome. Biol Direct. 2015:10:31. https://doi.org/10.1186/s13062-015-0061-x.

\section{Publisher's Note}

Springer Nature remains neutral with regard to jurisdictional claims in published maps and institutional affiliations. 